Adamo, "The Task and Distinctiveness," OTE 28/1 (2015): 31-52

\title{
The Task and Distinctiveness of African Biblical Hermeneutic(s) ${ }^{1}$
}

\author{
DAVID TUESDAY AdAMo (UNISA)
}

\begin{abstract}
This paper deals with the nature of African biblical hermeneutic(s), its task and distinctiveness. African biblical hermeneutic is the principle of interpretation of the Bible for transformation in Africa. It can also be called African cultural hermeneutic(s) or African biblical transformational hermeneutic(s) or African Biblical Studies. The task of African biblical hermeneutic(s) includes, firstly and foremost to formulation of a biblical hermeneutic that is "liberational and transformational"; secondly, to break the hermeneutical hegemony and ideological stranglehold that Eurocentric biblical scholars have long enjoyed; thirdly, to understand the Bible and God according to Scripture and African culture and tradition; fourthly, to interpret the Bible existentially; fifthly, to blacken the Bible; sixthly, to reappraise the Bible in order to correct the effect of the cultural ideological conditioning to which Africa and Africans have been subjected in the business of biblical interpretation; and seventhly, to promote African culture, tradition and identity. African biblical hermeneutic(s) has the following methodological distinctiveness: communal reading and interpretation, Bible as power, Africa and Africans in the Bible, African comparative, African evaluative, using Africa to interpret the Bible and using the Bible to interpret Africa, the promotion of distinctive life interest, and African identity.
\end{abstract}

Key concepts: Hermeneutics, Interpretation, African, Culture, Bible.

\section{A INTRODUCTION}

Is there any distinctiveness of African biblical hermeneutics? Can this distinctiveness be clearly stated? To most Euro-American biblical scholars the answer will probably be negative. But to most African biblical scholars who are knowledgeable in the meaning and purpose of African biblical hermeneutics, the answer will be positive. That is my assumption. Before this distinctiveness is enumerated, it is important to discuss briefly the definition and the task of

* Article submitted: 16 December 2013; article accepted: 8 August 2014. To cite: David T. Adamo, "The Task and Distinctiveness of African Biblical Hermeneutic(s)," OTE 28/1 (2015): 31-52, DOI: http://dx.doi.org/10.17159/2312-3621/2015/v28n1a4

1 This paper is a revised version of the paper presented at the meeting of the Society of Biblical Literature, Baltimore, USA, 23-26 November, 2013. 
African biblical hermeneutic(s) because it will serve as a necessary background to the understanding of the distinctiveness to be discussed.

It is also important to discuss the understanding of "African" in this paper. The word "African" is used in a broad sense. In this paper it is used to refer not only to people in the continent of Africa geographically and the people of black colour but also to embrace people of African descent all over the world and those who embrace African culture, religion and traditions. ${ }^{2}$ In other words, the boundary of Africa is extended to include all the people of African descents all over the world. ${ }^{3}$ That is why I think that the popular saying that if you can take me out of Africa, you cannot take away Africa in me is true.

What African biblical hermeneutic(s) is all about is bringing real life interest into the biblical text and then assign a very prominent role to this life interest. In this case the African context becomes the explicit subject of interpretation. There is a reason for the distinctiveness in African biblical hermeneutic(s). This reason has to do with the diversity of human distinctiveness and the recognition of this diversity in human distinctiveness. This also has to do with our different experiences and concerns. ${ }^{4}$ John Pobee's statement that biblical scholars should consider African tradition, religion and culture as "hermeneutics" in themselves, cannot be truer. Teresa Hinga also agrees with Pobee when she advised biblical scholars to shift from Eurocentric to Africentric hermeneutical approaches to biblical interpretation. ${ }^{5}$ The purpose of this paper is not to say that African biblical hermeneutic(s)s is the only biblical hermeneutic. It is one of the biblical hermeneutics that must be reckoned with among others. The purpose of this paper therefore, is to examine and bring to light, the actual task and distinctiveness of African biblical hermeneutics which are mainly found in African culture, religion and tradition.

\section{B DEFINITION OF AFRICAN BIBLICAL HERMENEUTIC(S)}

African biblical hermeneutic(s) is the principle of interpretation of the Bible for transformation in Africa. When we discuss the hermeneutic(s)s that can transform Africa we are discussing the biblical hermeneutics that is vital to the

2 David T. Adamo, Africa and Africans in the Old Testament (Eugene, Oreg.: Wipf and Stock Publishers, 2001). Originally published by Christian University Press, (Lanham, Maryland, 1998).

3 Adamo, Africa and the Africans in the Old Testament (Eugene: Wipf and Stock Publishers, 2001), 5.

4 Knut Holter, "Does A Dialogue Between Africa and Europe Make Sense?" in African and European Readers of the Bible in Dialogue (ed. Hans de Wit and Gerald O. West; Pietermaritzburg: Cluster Publications, 2009), 70-83.

5 Teresa Hinga, "Reading With: An Exploration of the Interface Between Critical and Ordinary Readings of the Bible: A Response," Semeia 73 (1996): 277-284. 
wellbeing of our society. This can be called African cultural hermeneutics or African biblical transformational hermeneutics or African biblical studies. ${ }^{6}$

African biblical hermeneutics is the biblical interpretation that makes "African social cultural context a subject of interpretation." It is the rereading of the Christian scripture from a premeditatedly Africentric perspective. Specifically, it means that the analysis of the biblical text is done from the perspective of African world-view and culture. ${ }^{8}$

This African biblical transformational hermeneutic(s) does not claim one-hundred percent objectivity. This is because a casual glance at the history of biblical hermeneutics reveals that there has never been an interpretation that has been without references to or dependent on a particular cultural code, thought patterns, or social location of the interpreter. ${ }^{9}$ There is no individual who is completely detached from everything in his or her environment or experience and culture so as to be able to render one hundred percent objectivity in every interpretation. The fact is that every interpreter is biased in some ways. ${ }^{10}$ Therefore, to talk of uniform, unconditional, universal, and absolute interpretation or hermeneutics is unrealistic. Such does not exist anywhere in this world. One who interprets tends to bring his or her own bias to bear, consciously or unconsciously, on the way in which the message is perceived.

6 Several terms are related to this transformational hermeneutics: inculturation hermeneutics, liberation hermeneutics, contextual hermeneutics, Africentric hermeneutics, and vernacular hermeneutics. From the above, African cultural hermeneutics is not done in absolute exclusion of western biblical mythology. It can be complimentary.

7 David T. Adamo, Reading and Interpreting the Bible in African Indigenous Churches (Eugene, Oreg.: WIPF and Stock Publishers, 2001); David T. Adamo, "African Cultural Hermeneutics," in Vernacular Hermeneutics, (ed. Rasia S. Sugirtharajah; Sheffield: Sheffield Academic Press, 1999), 60-90; Justin Ukpong, "Inculturation Hermeneutics: An African Approach to Biblical Interpretation," The Bible in A World Context: An Experiment in Contextual Hermeneutics (ed. Walter Dietrich and Ulrich Luz; Grand Rapids, Mich.: William B. Eerdmans Publishing Company, 2002), 17-32.

8 David T. Adamo, Explorations in African Biblical Studies (Eugene, Oreg.: WIPF and Stock Publishers, 2001), 6.

9 George Mulrain, "Hermeneutics Within a Caribbean Context," in Vernacular Hermeneutics (ed. Rasiah S. Sugirtharajah; Sheffield: Sheffield Academic Press, 1999), 116-132; David T. Adamo, "Reading Psalm 109 in African Christianity," OTE 21/3 (2008): 575-592; David T. Adamo, "What is African Biblical Studies?" in Decolonization of Biblical Interpretation in Africa (ed. Samuel. O. Abogunrin; Ibadan: Nigerian Association for Biblical Studies, 2005), 17-31.

10 Adamo, "What is African Biblical Studies?" 17-31. 


\section{THE TASK OF AFRICAN BIBLICAL HERMENEUTIC(S)}

From the above definition, the task of African biblical hermeneutic(s) seems clear. First and foremost, is to formulate a biblical hermeneutic that is "liberational and transformational." A casual look at biblical interpretation in Africa by Africans shows that our interpretation has been colonial. As far as I understand, colonialism is not limited to the partition of Africa and the eventual domination of the entire continent by the European nations; it includes the colonisation of our thought and the entirety of our way of life. Gerald West, a South African biblical scholar, acknowledges the fact that the Bible has been used by the oppressors in South Africa to justify the marginalisation of the indigenous population. The Bible as the symbol of God's presence among them has also been used by the oppressed as a tool for liberation. ${ }^{12}$ The fact is that biblical study has been colonised in Africa. Biblical hermeneutic(s) has also been colonised in various ways.

Second, which is closer to the above, is that the task is not only to understand the Bible and God in the African experience and culture, but also to "break the hermeneutical hegemony and ideological stranglehold that Eurocentric biblical scholars have long enjoyed." ${ }^{\prime 3}$ Although one appreciates the opportunity to study in many of these great Western universities and seminaries, one thing is certain, the overseas training in biblical studies and theology is one of the ways by which African biblical scholars have been colonised. Consciously and unconsciously, the establishment of churches became another means of colonising Africans. As discussed above, the African biblical scholars who are immersed in a Eurocentric approach to biblical interpretation and therefore colonised, passed on the colonisation to pastors and priests and other leaders. They then passed it on to their congregations who look for converts, not only to Christianity but also to Eurocentric Christianity. The result is that to think and interpret Africentrically has become a problem because we have been thoroughly Eurocentrically schooled. Another major means of colonisation of African biblical studies is the absolute domination of the field of biblical studies by Eurocentric scholars. Eurocentric scholars who write Eurocentrically write most of the commentaries, Bible Introductions, Bible Atlases, History of Ancient Israel, and major Bible Translations that we use in universities and seminaries all over the world. Not only are they Eurocentric in their approaches to biblical scholarship, they feverishly attempt to de-Africanise the Bible. Yet, that is what we read and consume in our universities and seminaries. These

11 Adamo, Explorations in African Biblical Studies, Eugene: Wipf and Stock Publishers, 2001, 53-68.

12 Gerald O. West, "Reading the Bible Differently: Giving Shape to the Discourses of the Dominated," Semeia 73 (2001): 22.

13 Adamo, Explorations, 9. Yorke calls this "Africentic Hermeneutics" which is very legitimate since all interpretations and theologies are perspectival. Gosnell L. Yorke, "Biblical Hermeneutics: An Afrocentric Perspective," JRTh 2/2(1995): 145-158. 
authors write with scholastic prejudice and hold tenaciously to the conception that the Eurocentric methods of biblical interpretation are "the interpretation." It is therefore superior and universal. This also has led to using Eurocentric criteria as a yardstick for judging all Africentric materials. There is an urgent need to break the hermeneutical hegemony and ideological stranglehold that Eurocentric biblical scholars have long enjoyed.

Third, African biblical hermeneutic(s) is faced with the task of reappraising the ancient biblical tradition and African world-view, culture, and life experience with the purpose of "correcting the effect of the cultural ideological conditioning to which Africa and Africans have been subjected" to in the business of biblical interpretation. ${ }^{14} \mathrm{An}$ example is the curse of Ham imposed on black people and therefore Africans in the Bible are slaves and declaration that African cultural hermeneutic is fetish, magical, and uncritical.

Fourth, African biblical hermeneutic(s) also has the task of promoting not only African culture, but African identity. Such African modes of interpretation "seek to acquire and celebrate their God-giving identity by delving into their indigenous resources and rejecting the superintending tendencies of western intellectual tradition." ${ }^{15}$ They address issues closer home to their own people. ${ }^{16}$ What they did was that they "learnt and borrowed ideas and techniques from external resources but reshaped them, often added their own indigenous texture, to meet their local needs."17 Our languages, songs, religion and entire culture are our identity for use in African biblical hermeneutic(s).

Fifth, our task is to understand God according to the scripture and culture of Africa. In African biblical hermeneutic(s), God is not considered a oneway track God. His mode of revelation to the world cannot be limited. God also reveals himself to Africans not only in the Bible but also in African indigenous religion and tradition. The real issue in African biblical hermeneutic(s), therefore, is using our finite human knowledge and experience of God to speak about God who is all embracing. The fact is that no one has yet been able to invent such language to encapsulate God's completeness. ${ }^{18}$

Sixth, the task of African Biblical Hermeneutic(s) includes "Blackening of the Bible." This means placing Africans at the center of the world. This is a vigorous attempt to use race as a tool for re-envisioning the landscape of the

14 Adamo, Reading and Interpreting, 47.

15 Rasiah S. Sugirtharajah, "Introduction" in Vernacular Hermeneutics (ed. Rasiah S Sugirtharajah; Sheffield: Sheffield Academic Press, 1999), 11.

16 Sugirtharajah, "Introduction," in Vernacular Hermeneutics, 12-13.

17 Rasiah S. Sugirtharajah, "Thinking about Vernacular Hermeneutics Sitting in a Metropolitan Study," in Vernacular Hermeneutics (ed. Rasiah S. Sugirtharajah; Sheffield: Sheffield Academy Press, 1999), 108.

18 George Mulrain, "Hermeneutics," 117-121. 
biblical world. This is a "true Africentricism," that is, the idea of placing Africa as an ideological construct at the center of biblical investigation that will serve as a useful tool for African scholars in our endeavor to create a hermeneutic that speaks to the needs of a historically marginalized people. ${ }^{19}$

Seventh, the task is also to interpret the Scripture existentially. Ukpong emphasized this point that Africans interpret the Bible existentially; this is a way of making interpretation relevant to every day experiences of Africans. An example of this is the Bible as power approach. The Bible, especially the Psalter is interpreted as an instrument of protection from evil forces, such as witches, wizard, and enemies. The Bible also becomes an instrument for healing diseases, especially the ones that modern medicines will not cure. The Bible is read, recited, sung, repeatedly to affect its desired healing. The Bible is also used for achieving success in live. This is as a result of the fact that the Bible is the word of God and the power of God in his word is unlimited, because it is sharper than two-edged sword (Heb 4:12).

\section{Distinctiveness of African Biblical Hermeneutic(s)}

Since African biblical hermeneutic(s) is in itself a distinctive methodology as defined above, the distinctiveness to be discussed below cannot but reflect a major distinctive methodology that reflects African culture and tradition.

\section{Communal Reading Approach}

One of the main distinctiveness of African biblical interpretation is the communal approach, that is, reading with the community. This has been referred to in various ways such as "reading with the Ordinary readers," "reading with the community," "reading with African eyes," reading with "residual illiterate people," "real contextual readers," "spontaneous and sub-conscious readers," "collaborative and interactive" readers. According to West, ordinary readers are ordinary people, the poor and the marginalised communities. ${ }^{20}$ According to Draper they are those who are working with residual oral culture who employ residual oral hermeneutic in their readings. ${ }^{21}$ The ordinary readers are also identified as "real contextual readers." These ordinary readers are also identified as spontaneous and sub-conscious readers because they read sub-consciously and spontaneously for direct use in their social location. ${ }^{22}$ Eric Anum

19 Michael J. Brown, Blackening of the Bible: The Aims of African American Biblical Scholarship (Harrisburg: Trinity Press International, 2004), 54.

20 West, "Reading the Bible Differently," 21-41.

21 Jonathan Draper, "Confessional Western Text-Centered Biblical Interpretation and Oral Residual Text," Semeia 73 (1996): 59-77.

22 Daniel Patte, "Biblical Scholars at the Interface between Critical and Ordinary Readings: A Response,” Semeia 73 (1996): 263-276. 
calls their reading "collaborative and interactive hermeneutic." 23 Ukpong gave a common element in African worldviews and culture, that is, the sense of a community. ${ }^{24}$ West also discusses this type of reading "Reading other-wise." Jonker advocated for a communal approach to the reading and interpretation of the Bible and listed many benefits of it. ${ }^{25}$

(i) It helps one to find his/her identity among the community of scholars.

(ii) It helps African biblical scholars to intensify the diversity and make use of the diversity in the global community.

(iii) It helps scholars to eradicate the individualist and exclusivist tendencies in biblical scholarship that seems to characterise Eurocentric biblical scholarship.

(iv) It helps to "open a discourse on our interpretation."

(v) It offers one the very opportunity of investigating the relationship of the community of theological and hermeneutical discourse. Jonker also calls it a multidimensional methodology.

After all, the Bible is a community document. According to Riches, both ordinary and scholarly readers belong to "a community of readers." 26 Without doubt, the interchange between the ordinary and the scholarly readers helps to influence the understanding of the text in different ways and the way the Bible functions in each context. ${ }^{27}$ At the end of the reading practiced together, the subjectivities of both readers are enlarged. ${ }^{28}$

The fact is that ordinary Africans and non-scholarly interpreters are constitutive of our scholarship in ways that I think is not the case in current Euro-American practice. ${ }^{29}$ Others may read the Bible in a communal setting in

23 Eric Anum, "Collaborative and Interactive Hermeneutics in Africa: Giving Dialogical Privilege Biblical Interpretation," in African and European Readers of the Bible in Dialogue (ed. Hans de Wit and Gerald O. West; Pietermaritzburg: Cluster Publication, 2009), 143-165.

24 Justin Ukpong, "Reading the Bible with African Eyes: Inculturation and Hermeneutics," JTSA 91 (1995): 3-14.

25 Louis Jonker "Toward a Communal Approach for Reading the Bible in Africa," in Interpreting the Old Testament in Africa (ed. Mary Getui, Knut Holter and Victor Zinkuratire; New York: Peter Lang, 1999), 76-88.

26 John Riches, "Interpreting the Bible in African Contexts: Glasgow Consultation," Semeia 73 (1996): 181-188.

27 West, "Reading the Bible Differently," 21-41.

28 West, "Reading the Bible Differently," 37-38.

29 Justin Ukpong, "Bible Reading with a Community of Bible Readers" in Interpreting the New Testament in Africa (ed. Mary Getui, Tinyiko Maluleke and Justin Ukpong; Nairobi: Acton Press, 2001), 188-212; Gerald West, "Unpacking the Pack- 
the West and other Third World continents such as Latin America, but the nature of the communities is not African. The nature of the discussion and approach to the reading is not controlled by African perspective. The conclusion reached does not reflect African culture.

\section{The Bible as Power Approach}

An important distinctive development in African biblical hermeneutic(s) is the Bible as power approach. This is an existential and reflective approach to the interpretation of the Bible. Unlike the Eurocentric conservative and biblical scholars who were preoccupied with the subject of inerrancy and infallibility of the Bible, African Christians believe and respect the Bible without any attempt to defend it and apologise for it. The Bible is the Word of God and is powerful and its power is relevant to everyday life of Africans. ${ }^{30}$

The Bible is used as means of protection where the fear of witches and wizards is the order of the day. The power of the Bible is also used therapeutically for healing where there is prevalence of diseases without the means of access to hospitals. The Bible is used as means of success where there is a prevalence of abject poverty. Although this practice is mostly in the African indigenous churches, it has spread to not only the Pentecostal churches but also the mission churches and the African Diaspora. African indigenous Churches became dissatisfied with the Eurocentric methods of biblical interpretation employed by the missionary mainland churches' self imposition of the structure of Western institutions at the expense of African culture. They recognised that many of the Eurocentric interpretations and theology nourished in a Western biblical intellectualist context had no root in the life of the African community. A Western approach to the interpretation of the Bible became unprofitable. They therefore had to form their own African indigenous churches that would meet the needs of the African communities by employing African culture in their interpretation of the Bible. Investigation has revealed that African indigenous churches have used the Bible as the Word of God and recognised the

age that is the Bible in African Biblical scholarship," in Reading the Bible in the Global Village: Cape Town (ed. Alpheus Masoga et al.; SBLGPBS 8; Atlanta: Society of Biblical Literature, 2002), 65-94.

30 Zablon Nthaburi and Douglas Waruta, "Biblical Hermeneutics in African Instituted Churches," in The Bible in African Christianity (ed. Hanna W. Kinoti and John Mwalligo; Nairobi: Acton Publishers, 1997), 40-57; Adamo, "African Cultural Hermeneutics," 66-90; David T. Adamo, "Decolonizing the Psalter," in Postcolonial Perspectives in African Biblical Interpretations (ed. Musa W. Dube, Andrew M. Mbuvi, and Dora R. Mbuwayesango; SBLGPBS 13; Atlanta: Society of Biblical Literature, 2012), 299-316; David T. Adamo, "The Historical Development of Old Testament Interpretation in Africa," OTE 16/1 (2003): 9-33, 299-316; Adamo, Reading and Interpreting, 45-48; Adamo, "African Cultural Hermeneutics," 7-39. 
power inherent in it. The Bible has been used for healing, protection and success in life.

Considerable African scholars have made important investigations to the use of the Bible as power. Solomon O. Ademiluka wrote about "The Use of Therapeutic Psalms in Inculturating Christianity in Africa." ${ }^{31}$ Adamo also made some important contributions in his books and articles on this line such as "The Use of African Indigenous Medicine in African Indigenous Churches in Nigeria"; "The Distinctive Use of Psalms in African Independent Churches in Nigeria," ${ }^{33}$ Reading and Interpreting the Bible in African Indigenous Churches, and others. ${ }^{34}$

The tendency of many Euro-American scholars is to denounce this distinctive African approach to biblical interpretation as fetish, magical and syncretistic and unscholarly. But a closer examination of the interpretation shows that care must be taken. Is it likely that ancient Israelites used the book of Psalms and other parts of the Bible for protection, for healing and success according to the culture of the ANE? There is the likelihood that such was the way that the ancient Israelites actually interpreted and used the words of Psalms in their worship. Important evidence supporting the use of amuletic inscriptions by ancient Israelites supports the possibility that such was the way the ancient biblical people used the Bible during their time. According to some biblical archaeologists there is the existence of a handful of Phoenician and Punic amulets from the first millennium with the same verbs "guard," (smr) and "protect" ( $n s r)$ in the book of Psalms inscribed on their surfaces. "The presence of these two verbs in both West Semitic inscriptions and the book of Psalms show some common cultural and religious practices and common purpose for invoking the deity's protection or help. ${ }^{36}$ Inscribing words in metal and apotropaic magic in ancient Israel is not uncommon as uncovered by archaeologists. ${ }^{37}$ Several 7 th to 6 th century Punic gold bands were discovered during the

31 Solomon O. Ademiluka, "The Use of Therapeutic Psalms in Inculturating Christianity in Africa," (M.A. diss., University of Ilorin, 1991).

32 David T. Adamo, "The Use of African Indigenous Medicine in African Indigenous Churches in Nigeria," BICUAER 39 (1997-1998), 73-101.

33 David T. Adamo, "The Distinctive Use of Psalms in African Independent Churches in Nigeria," MJT 9/2 (1993): 94-111.

34 Adamo, Reading and Interpreting, 45-48.

35 Jeremy Smoak, "Amuletic Inscriptions and the Background of YHWH as Guardian and Protector in Psalm 12," VT 60 (2010): 421-432; Jeremy Smoak, "Prayers of Petition in the Psalms and West Semitic Inscribed Amulets: Efficacious Words in Metal and Prayers for Protection in Biblical Literature," JSOT 36/1 (2011): 75-92.

36 Smoak, "Prayers of Petition," 75-92.

37 Smoak, "Prayers of Petition," 75-92. 
excavations at Carthage with the same two verbs inscribed as part of protective formula like that of Psalms. ${ }^{38}$

It is certain that the culture of the ANE makes one believe that the words of the Psalter were memorised and recited not for fun or aesthetic or scholarly purposes, but for the faith behind the recitation or singing or chanting of the Psalms, with the expectation that they would achieve a desired effect. In ancient Israel, those words were potent and performative words that sought to invoke a particular result. Like the ancient Israelites, who were the original authors of the Psalter, many African biblical scholars see the Psalter as divine, potent and performative. They can be used to protect one from enemies; they can heal diseases and bring about success. A few eminent biblical scholars (E. Jacob, W. Eichrodt, O. Prockesh, G. Von Rad, G. A. F. Knight and R. Bultmann) agree with African biblical scholars that the spoken word in ancient Israel was "never an empty sound but an operative reality whose action cannot be hindered once it has been pronounced.",39

\section{Africa and Africans in the Bible Approach}

Another very important distinctiveness in African biblical hermeneutics is Africa and Africans in Bible approach. Ukpong was emphatic that Africa and Africans in the Bible calls for a methodological approach that cannot be ignored. $^{40}$ This method reaches its peak during 1990 s to the present. It discusses the presence and the contributions of Africa and Africans in the Bible. To my knowledge no biblical interpretation searches for the presence and the contribution of Africa and Africans in the Bible. Africa and Africans are mentioned in every strand of biblical literature. ${ }^{41}$ African biblical scholars continue

38 Smoak, "Prayers of Petition," 75-92; Charles R. Krahmalkov, Phoenician-Punic Dictionary (Leuven: Peeters, 2000), 471-472.

39 Edmond Jacob, Theology of the Old Testament (London: London University Press, 1958), 127; Walther Eichrodt, Theology of the Old Testament (vol. 2; London: London University Press, 1967), 69; Otto Procksch, "The Word of God in the Old Testament," TDNT 4:93; Gerhard von Rad, Old Testament Theology (vol. 2; Edinburgh: T \& T Clark, 1965), 85; G. A. F. Knight, A Biblical Approach to the Doctrine of the Trinity (Edinburgh: T \& T Clark, 1953), 14-16; Rudolph Bultmann, "The Concept of the Word of God in the New Testament," in Faith and Understanding (vol. 1; ed. Rudolph Bultmann; London: London University Press, 1969), 287-297. For detail summary of the other scholars see Anthony C. Thielton, "The Supposed Power of Words," JTS 25/2 (1974): 183-299.

40 Justin Ukpong, "Development in Biblical Interpretation in Africa: Historical and Hermeneutical Directions," in The Bible in Africa (ed. Gerald West and Musa Dube; Boston: Brill, 2000), 11-28.

41 David T. Adamo, Africa and the Africans in the Old Testament (Eugene, Oreg.: Wipf and Stock, 2001), 51, 81, 15; David T. Adamo, Africa and Africans in the New Testament (Lanham: University Press of America, 2006). The entire book deals with 
to use Africa and Africans in their methodology and discovered that Africa and Africans were mentioned more than 1700 times in the Bible and they come to the conclusion that the Bible would have never be in the shape it is now without Africa and African participation in the drama of redemption. African biblical scholars continue to demonstrate the importance and influence of Africa and Africans in the Bible. ${ }^{42}$ African biblical scholars also demonstrate that the Bible is not only an ancient Jewish document alone it is also an African document. Through this approach we find that there is no prejudice against Africa and Africans in the Bible. The present prejudice by some Western biblical interpreters is a modern invention.

Many African biblical scholars have made much progress. Teresa Okure's article, "Africans in the Bible: A Study of Hermeneutics," 43 in Adamo's book has made some important contributions between 1980 and 2014. The following are worth mentioning: Africa and Africans in the Old Testament, Africa and Africans in the New Testament, "The African queen and Examination of I Kings 10:1-13,"44"The Table of Nations in an African Context," "Ethiopia in the Bible,"46 "Ancient Africa and Genesis 2:10-14,"," "Images of Cush in the Old Testament: A Reflection on African Biblical Hermeneutics," "In Search of Africanness in the Bible,"49 "The African Wife of Moses,"50 "The

how Africa and Africans were mentioned in the Gospel, Acts of the Apostles and the Epistles.

42 Vincent Wimbush, "Scripture for Strangers: The Making of an Africanized Bible," in Postcolonial Interventions (ed. Tat-Siong Liew; Sheffield: Sheffield Phoenix Press, 2009), 162-177; Cain H. Felder, "Race, and Biblical Narratives," in Stony the Road We Trod: African American Biblical Interpretation (ed. Cain H. Felder; Minneapolis: Fortress Press, 1991), 127-145; Charles Copher, "Black Presence in the Old Testament," in Stony the Road We Trod: African American Biblical Interpretation (ed. Cain H. Felder; Minneapolis: Fortress Press, 1991), 146-164; Randall B. Bailey, "Beyond Identification: The Use of Africans in the Old Testament Poetry and Narratives," in Stony the Road We Trod: African American Biblical Interpretation (ed. Cain H. Felder; Minneapolis: Fortress Press, 1991), 165-186.

43 Teresa Okure, "Africans in the Bible: A Study of Hermeneutics" (paper presented at the annual meeting of SBL, New Orleans, 21-23 November, 1996).

44 David T. Adamo, "The African Wife of Solomon (I Kings 3:1;9:16; 7:8;11:1)" JSem 23/1 (2014): 1-20.

45 David T. Adamo, "The Table of Nations in an African Context," JARP 2/2 (1993): $2-15$

46 David T. Adamo, "Ethiopia in the Bible," ACS 8/2 (1992): 51-54.

47 David T. Adamo, “Ancient Africa and Genesis 2:10-14,” JRT 47/1 (1992): 33-43.

48 David T. Adamo, "Images of Cush in the Old Testament: A Reflection on African Biblical Hermeneutics," Interpreting the Old Testament in Africa (ed. Mary Getui, Knut Holter and Victor Zinkuratire; New York: Peter Lang, 2001), 65-74.

49 David T. Adamo, "In Search of Africanness in the Bible," NJBS 15/2 (2000): 2040 . 
African Wife of Abraham,"51،"The Nameless African Wife of Potiphar and Her contribution to Ancient Israel," 52 "The African Wife of Jeroboam," 53 "The African Wife of Joseph," 54 and the African Wife of Solomon." ${ }^{55}$ Many African Americans are also pioneers in the field of using Africa and Africans in the Bible methodology. When this writer's paper was sent for assessment, one of the Eurocentric assessor's comments was, "this author is trying to smuggle Africa into the Bible." Moreover, saying that Egypt is part of Africa was also questioned.

Many Eurocentric scholars have not shown much interest except a Norwegian scholar, a colleague and a friend, Knut Holter, who has published many books and articles using Africa and Africans in the Bible. He wrote, "Should Old Testament Cush be rendered Africa?" and Yahweh in Africa. He seems to be the only outstanding Western African Biblical scholar who is deeply interested in this area of using Africa and Africans in the Bible Methodology among Euro-Americans. ${ }^{58}$

\section{$4 \quad$ African Comparative Approach}

Another important distinctiveness in African biblical hermeneutic is African comparative approach. Of course, there are many types of comparative approaches to biblical interpretation. Many Eurocentric interpreters are preoccupied with comparing the Bible with the so-called ANE which they say includes Egypt. Yet when they compare the Bible with Egypt, they do that as if Egypt is a European country or as if it is not part of Africa even geographically. Ancient Israelite ancestors once lived in Africa for about 430 years and by the time they left Africa they were all African-Israelites. This was discussed in

50 David T. Adamo, "The African Wife of Moses: An Examination of Numbers 12:1-9," ATJ 8/3 (1989): 230-237.

51 David T. Adamo and Erivwierho F. Eghwubare, "The African Wife of Abraham," OTE 18/3 (2005): 455-471.

52 David T. Adamo, "The Nameless African Wife of Potiphar and Her Contribution to Ancient Israel," OTE 26/2 (2013): 221-246.

53 David T. Adamo, "The African Wife of Jeroboam (Ano?): An African Reading of I Kings 14," ThViat 37/2 (2013): 71-89.

54 David T. Adamo, “The African Wife of Joseph,” Jsem 22/2 (2013): 409-425.

55 Adamo, "Wife of Solomon," 1-20.

56 Knut Holter, "Should Old Testament Cush be Rendered African?" BT 48 (1997): 331-336.

57 Knut Holter, Yahweh in Africa: Essays on Africa and the Old Testament (BTA 1; New York: Peter Lang, 2000).

58 Knut Holter, "Africa in the Old Testament," in The Bible in Africa: Transactions, Trajectories, and Trends (ed. Gerald O. West and Dube Musa; Leiden: Brill, 2000), 569-581. 
detail in "A Mixed Multitude: Exodus 12:38 in African Context." ${ }^{59}$ This comparative approach compares the Bible text, religion and culture with the African text, religion and culture. This comparison of Africa and the Bible and Christianity brings out the relevance of African culture to the study of OT and the OT to Africa and Africans. Michael G. Swanepoel wrote "An Encounter between Old Testament Theology and African Concepts of God" which brought out this relevance. ${ }^{60}$ Other publications include Awonrinde's "A Comparative Analysis of Destiny in the Old Testament and in Yoruba Philosophy of Life," 61 and Adamo's use of comparative methodology in "Understanding the Genesis Creation Account in an African Background." 62 Madipoane Masenya wrote "Wisdom and Wisdom Converge: Selected Old Testament and Northern Sotho Proverbs," "63 "For Better for Worse? The (Christian) Bible and Africana Women," and "A Small herb increases itself (makes impact) by a strong odour': Reimagining Vashti in an African South African Context." "There were also many doctoral theses such as "A Comparative Study of transmissions, actualization and Stabilization of oral Traditions: An examination of traditions of Circumcision in Africa and Ancient Israel" by S. N. Gitau, "A Comparative Analysis of Destiny in the Old Testament and in Yoruba Philosophy of Life" by John Ademola Aworinde, "Perspective on the Problem of Poverty in Traditional Africa and in Ancient Israel" by Robert

59 David T. Adamo, "A Mixed Multitude: An African Reading of Exodus 12:38," in Exodus and Deuteronomy (ed. Gale Yee and Athalya Brenner; Minneapolis: Fortress Press, 2012), 67-78.

60 Michael G. Swanepoel, “An Encounter between Old Testament Theology and African Concepts of God," ThViat 18 (1990): 20-30.

61 John A. Aworinde, "A Comparative Analysis of Destiny in the Old Testament and in Yoruba Philosophy of Life," (Ph.D. diss., University of Jos, Nigeria, 1997).

62 David T. Adamo, "Understanding the Genesis Creation Account in an African Background," CJRS 10/2 (1989): 17-25; see also David T. Adamo, "Genesis Creation Accounts: An African Background," in Genesis (ed. Athalya Brenner, Archie Chie Chung Lee, and Gale A. Yee; Minneapolis, Minn.: Fortress Press, 2010), 25-34.

63 Madipoane Masenya (ngwan'a Mphahlele), "Wisdom and Wisdom Converge: Selected Old Testament and Northern Sotho Proverbs," in Interpreting the Old Testament in Africa (ed. Mary Getui, Knut Holter and Victor Zinkuratire; New York: Peter Lang, 2001), 133-146.

64 Madipoane Masenya (ngwan'a Mphahlele), "For Better for Worse? The (Christian) Bible and Africana Women," OTE 22/1 (2009): 126-150; Madipoane Masenya (ngwan'a Mphahlele), "A Small Herb Increases itself (makes impact) by a strong odour': Reimagining Vashti in an African South African Context," OTE 16/2 (2003): 332-342.

65 Samson N. Gitau, “A Comparative Study of Transmissions, Actualization and Stabilization of Oral Traditions: An Examination of Traditions of Circumcision in Africa and Ancient Israel," (Ph.D. diss., Boston University, 1994).

66 Aworinde, "A Comparative Analysis." 
Wafawanaka, "God and Nature in Genesis 1:1-2:4 and Chewa Cosmogony" by R. W. Kawale, "A Ngoni Assessment of the Role of Ancestors within Israelite worldviews and religion in Genesis 11:28-50:26" by Edwin Zulu, ${ }^{69}$ and "Genesis Account of Creation and the Fall in an African Setting" by Solomon O. Ademiluka. ${ }^{70}$ The fact is that in this African comparative approach African materials become the major dialogue and partner. The advantage is that African culture and religion are valued. ${ }^{71}$

\section{$5 \quad$ African Evaluative Approach}

An important distinctiveness of African biblical hermeneutic(s) is an African evaluative approach. ${ }^{72}$ An evaluative approach has to do with African and nonAfrican biblical scholars mostly specialising in their books or essays in criticising the works of African biblical scholars. This type of criticism may be constructive, negative or both. This criticism is only for progress, correction and readjustment in African biblical studies. There are some African biblical scholars who are good at this. Prof Knut Holter and Marta Hoyland, both Norwegians, are at the forefront. Yahweh in Africa which deals with such constructive criticism is concerned with excellence in African OT studies. Holter also decried the marginalisation of African OT studies by Euro-American scholars and some African scholars themselves. ${ }^{73} \mathrm{He}$ also criticised my interpretation of all Cush passages as Africa. ${ }^{74}$ Despite his criticism of my work he still rated it so far then as the most prolific and productive African OT scholarly work. Despite his criticism of my work, he still think that I was "probably the African scholar who has made the single most important contribution to the

67 Robert Wafawanaka, "Perspective on the Problem of Poverty in Traditional Africa and in Ancient Israel," (Ph.D. diss., Boston University, 1997).

68 Winston R. Kawale, "God and Nature in Genesis 1:1-2:4 and Chewa Cosmogony," (Ph.D. diss., University of Stellenbosch, South Africa, 1998).

69 Edwin Zulu, "A Ngoni Assessment of the Role of Ancestors within Israelite Worldviews and Religion in Genesis 11:28-50:26," (Ph.D. diss., University of Stellenbosch, South Africa, 1999).

70 Solomon O. Ademiluka, "Genesis Account of Creation and the Fall in an African Setting," (Ph.D. diss., University of Ilorin, Nigeria, 1998).

71 Knut Holter, "Does Dialogue between Africa and Europe Make Sense?" in Africa and European Readers of the Bible in Dialogue," (ed. Hans de Wit and Gerald West, Pietermaritzburg: Cluster Publications, 2009), 69-80.

72 Adamo, "The Historical Development," 25.

73 Knut Holter, "It is Not Only a Question of Money! African Old Testament Scholarship between the Myths and Meanings of the South and the Money and Methods of the North," OTE 11 (1998): 240-254.

74 Holter, Yahweh in Africa, 107-114; Marta Hoyland, "An African Presence in the Old Testament? David Tuesday Adamo's Interpretation of the Old Testament Cush Passages," OTE 11 (1998): 50-58. 
field of African presence in the Old Testament." ${ }^{, 75}$ These criticisms care valuable because they help us to know which area to improve.

\section{Using Africa to Interpret the Bible}

A method that is also distinctive is the use of Africa and Africans to interpret the Bible and using the Bible to interpret Africa. ${ }^{76}$ A combination of the historical-critical method and anthropological/sociological methods are used. While the historical-critical method is used only to analyse the text, the anthropological/sociological method is use to analyse the African culture and situation or the purpose of understanding a particular biblical text in the light of African tradition and situation for the purpose of arriving at an authentic Christianity that is both African and biblical. ${ }^{77}$ An example of this type of research is E. A. McFall's "Approaching the Nuer through the Old Testament" and "Using Nuer Culture of Africa in understanding the Old Testament: Evaluation.",78

\section{$7 \quad$ Distinctive Interest}

Another distinction of African biblical hermeneutic(s) is the type of interest that African biblical interpreters bring to the texts. According to Gerald West, there are two major interests that interpreters usually bring to the texts. Interpreters usually come to the text with what we may call interpretative interests and life interests. ${ }^{79}$ The distinctiveness of African Biblical interpreters is that they bring life interests to the interpretation of the Bible while the EuroAmerican interpreters bring interpretative interests to the text. While interpretative interests refer to those dimensions of the text that interest the interpreters, life interests are those concerns and commitments that drive or motivate the interpreters to come to the texts. In such a case such concerns and commit-

75 Marta Hoyland, "The 'African' Texts of the Old Testament and their African Interpretations," in Interpreting the Old Testament in Africa (ed. Mary Getui, Knut Holter, and Victor Zinkuratire; New York: Peter Lang, 2001), 43-54.

76 Justin Ukpong, "Development," 16-17; Serapio Kabazzi Kisirinya, "Interpreting the Old Testament in Africa: Last Will, Contract or Covenant," in Interpreting the Old Testament in Africa (ed. Mary Getui, Knut Holter and Victor Zinkuratire; New York: Peter Lang, 2001), 189-192; Pauline Otieno, "Interpreting the Book of Psalms in the Coptic Orthodox Church of Kenya," in Interpreting the Old Testament in Africa (ed. Mary Getui, Knut Holter and Victor Zinkuratire; New York: Peter Lang, 1999), 159164.

77 Ukpong, “Development," 16.

78 Ernest A. McFall, Approaching the Nuer through the Old Testament (Pasadena: William Carey Library, 1970), 8; David Fiensy, "Using Nuer Culture of Africa in Understanding the Old Testament: Evaluation," JSOT 38 (1987): 73-83.

79 Gerald O. West, "Interrogating the Comparative Paradigm in African Biblical Scholarship," in African and European Readers of the Bible in Dialogue (ed. Hans de Wit and Gerald O. West; Pietermaritzburg: Cluster Publications, 2009), 37-64. 
ments shape the very questions that are brought to the biblical text. ${ }^{80}$ This life interests may pertain to healing, protection and success in life. They may be religious, cultural and socio-political commitments. They may be race, class, or gender. So when African biblical interpreters come to the Bible they want to know what the text has to offer concerning these things. But majority of Western biblical scholars come to the text with questions regarding the historical, social, and literary dimensions of the text. ${ }^{81}$

\section{African Christian Identity}

Ninian Smart identifies six different things that are important to identity: social institutions, ethical teachings, rituals, religious experiences, myths and doctrine. ${ }^{82}$ A casual look the history of biblical hermeneutic reveals the fact that no hermeneutic reveals the African Christian identity like African biblical hermeneutic(s). As far as African and Christian identity is concerned several key concepts are important. They are indigenisation, contextualisation, inculturation, Africanisation and others. All these concepts are utilised and very important to African biblical hermeneutic(s). ${ }^{83}$

African biblical hermeneutics give readers and interpreters the opportunity of self-awareness and self-identity. Interpreting with the poor brings the biblical interpreters to become aware of his/her own hidden preoccupations or antipathies during conversation. As the text is discussed, African biblical scholars are aware of the fact that he or she has been colonised by EuroAmerican theories of biblical interpretation. ${ }^{84}$

\section{$9 \quad$ Blackening the Bible}

The blackening of the Bible is not limited to black colour. It includes African culture, religion all over the world and, of course, the African continent. This blackening of the Bible is culture one of the distinctive aspects of African Biblical Hermeneutics. This blackening of the Bible means placing Africa and Africans at the centre of the biblical world and our biblical interpretation. This also means a vigorous attempt to use race, religion and culture as a tool for reenvisioning the landscape of the biblical world and interpretation. This is a "true Africentricism," that is, the idea of placing Africa as an ideological construct at the centre of biblical investigation that will serve as a useful tool for African scholars in our endeavour to create a hermeneutic that speaks to the

80 West, "Interrogating," 37-64.

81 West, "Interrogating," 37-64.

82 Ninian Smart, The Phenomenon of Religion (London: Mowbrays, 1973), 42-43; Ninian Smart, The Religious Experience of Mankind (New York: Collins, 1969), 1225. See also Ernst M. Conradie, Christian Identity: An Introduction (Stellenbosch: Sun Press, 2005), 20.

83 Conradie, Christian Identity, 8.

84 Anum, "Collaborative," 143-165. 
needs of a historically marginalised people. ${ }^{85}$ Many Africans and African Americans such as Charles Copher, Randall Bailey, Cain Hope Felder, Vincent Winbush, Madipoane Masenya, Musa W. Dube, Dora Mbuwayesango, Andrew Mbuvi, Gerald West, David Adamo, Knut Holter, a Norwegian scholar, and so many others who are engaged in African biblical hermeneutics are doing their best in blackening the Bible in our interpretation. In fact, one can say with great confidence that the people referred to as ancient Israelites were also Africans. That is why they are called African/Israelite because by the time they left Egypt/Africa after 430 years, having eating African food, wore African clothes, danced African dance, spoke African language, and were immersed in African culture, it will be unrealistic for any scholar to deny the fact that they were African-Israelites. ${ }^{86}$

\section{CONCLUSION}

This paper has enumerated the tasks and the distinctiveness of African biblical hermeneutic(s). In a summary way these were: to formulate a biblical hermeneutic that is both transformational and liberational; to break the hermeneutical hegemony that Eurocentric biblical scholars have long enjoyed; to understand the Bible and God in the light of African culture and tradition; to interpret the Bible existentially; to blacken the Bible; and to correct the effect of the ideological conditioning to which Africa and Africans have been subjected; and to promote African culture, tradition and identity.

The distinctiveness include: reading with the community, the Bible as power; African comparative approach, and evaluative approach; using Africa to interpret the Bible, African and Africans in the Bible approach; and blackening the Bible. The above indicate that the future of African biblical scholars is bright and the struggle to fulfil the task and the distinctiveness must continue.

The temptation for a non-African biblical scholar when reading this article is to think that the purpose of African biblical hermeneutic(s) is to advocate a placement or a dismissal of Eurocentric approach. The purpose of this paper is not to condemn other methodologies or say that the task and the distinctiveness of African Biblical Hermeneutic(s) is the only legitimate and universal one, but that it is one of the legitimate methodologies. As said above it is not in isolation because it interacts and builds on other hermeneutics to certain extent. The task and the distinctiveness discussed above attempts to decolonise the interpretation of the Bible in the light of African culture and tradition.

85 Brown, Blackening of the Bible, 54.

86 Adamo, "A Mixed Multitude," 67-7. 
48 Adamo, “The Task and Distinctiveness," OTE 28/1 (2015): 31-52

\section{BIBLIOGRAPHY}

Adamo, David T. "Understanding the Genesis Creation Account in an African Background." Caribbean Journal of Religious Studies 10/2 (1989): 17-25. . "The African Wife of Moses: An Examination of Numbers 12:1-9." African Theological Journal 8/3 (1989): 230-237. . "Ancient Africa and Genesis 2:10-14." Journal of Religious Thought 47/1

(1992): 33-43. . "Ethiopia in the Bible. "African Christian Studies 8/2 (1992): 51-54.

."The Table of Nations in an African Context. "Journal of African Religion and Philosophy 2/2 (1993): 2-15. . "The Distinctive Use of Psalms in African Independent Churches in Nigeria." Melanesian Journal of Theology 9/2 (1993): 94-111. ."The Use of African Indigenous Medicine in African Indigenous Churches in Nigeria." Bulletin of the International Committee on Urgent Anthropological and Ethnological Research 39 (1997-1998): 73-101.

."African Cultural Hermeneutics." Pages 60-90 in Vernacular Hermeneutics. Edited by R. S. Sugirtharajah. Sheffield: Sheffield Academic Press, 1999. . Africa and Africans in the Old Testament. Eugene, Oreg.: Wipf and Stock, 2001. Originally published by Christian University Press, Lanham, Maryland, 1998.

. "In Search of Africanness in the Bible." Nigerian Journal of Biblical Studies 15/2 (2000): 20-40. . Explorations in African Biblical Studies. Eugene, Oreg.: WIPF and Stock Publishers, 2001. ."Images of Cush in the Old Testament." Pages 65-74 in Interpreting the Old Testament in Africa. Edited by Mary Getui, Knut Holter, and Victor Zinkuratire. New York: Peter Lang, 2001. . Reading and Interpreting the Bible in African Indigenous Churches. Eugene, Oreg.: WIPF and Stock Publishers, 2001. ."The Historical Development of Old Testament Interpretation in Africa." Old Testament Essays 16/1 (2003): 9-33. ."What is African Biblical Studies?" Pages 17-31 in Decolonization of Biblical Interpretation in Africa. Edited by Samuel O. Abogunrin. Ibadan: Nigerian Association for Biblical Studies, 2005. . Africa and Africans in the New Testament. Lanham: University Press of America, 2006. ."Reading Psalm 109 in African Christianity." Old Testament Essays 21/3 (2008): 575-592. . "Genesis Creation Account: An African Background." Pages 25-34 in Genesis. Edited by Athalya Brenner, Archie Chie Chung Lee, and Gale A. Yee. Minneapolis, Minn.: Fortress Press, 2010.

."Decolonizing the Psalter." Pages 299- 316 in Postcolonial Perspectives in African Biblical Interpretations. Edited by Musa W. Dube, Andrew M. Mbuvi, and Dora R. Mbuwayesango. Society of Biblical Literature Global Perspectives on Biblical Studies 13. Society of Biblical Literature: Global Perspectives on Biblical Scholarship. Atlanta: Society of Biblical Literature, 2012. 
."A Mixed Multitude: An African Reading of Exodus 12:38." Pages 67-78 in

Exodus and Deuteronomy. Edited by Gale Yee and Athalya Brenner.

Minneapolis: Fortress Press, 2012.

. "The African Wife of Solomon (I Kings 3:1;9:16; 7:8;11:1)." Journal for

Semitics 23/1 (2014): 1-20.

."The African Wife of Jeroboam (Ano?): An African Reading of I King 14:1-

18." Theologia Viatorum 37/2 (2013): 71-89.

. "The Nameless African Wife of Potiphar and Her Contribution to Ancient

Israel." Old Testament Essays 26/2 (2013): 221-246.

."The African Wife of Joseph, Asenath (Gn. 41:45, 50; 46:20)." Journal for

Semitics 22/2 (2013): 409-425.

Adamo, David T. and Erivwierho F. Eghwubare. The African Wife of Abraham." Old Testament Essays 18/3 (2005): 455-471.

Ademiluka, Solomon Olusola. "The Use of Therapeutic Psalms in Inculturating Christianity in Africa." M.A. diss., University of Ilorin, 1991.

. "Genesis Account of Creation and the Fall in an African Setting." Ph.D.

diss., University of Ilorin, Nigeria, 1998.

Anum, Eric. "Collaborative and Interactive Hermeneutics in Africa: Giving Dialogical

Privilege in Biblical Interpretation." Pages 143-165 in Africa and European

Readers of the Bible in Dialogue. Edited by Hans de Wit and Gerald O. West.

Pietermaritzburg: Cluster Publications, 2009.

Aworinde, John A. "A Comparative Analysis of Destiny in the Old Testament and in Yoruba Philosophy of Life.” Ph.D. dissertation, University of Jos, Nigeria, 1997.

Bailey, Randall B. "Beyond Identification: The Use of Africans in the Old Testament Poetry and Narratives." Pages 165-186 in Stony the Road We Trod: African American Biblical Interpretation. Edited by Cain H. Felder. Minneapolis: Fortress Press, 1991.

Brown, Michael J. Blackening of the Bible: Aims of African American Biblical Scholarship. Harrisburg: Trinity Press International, 2004.

Bultmann, Rudolph. "The Concept of the Word of God in the New Testament." Pages 287-297 in Faith and Understanding. Edited by Michael Strange. London: London University Press, 1969.

Copher, Charles. "Black Presence in the Old Testament." Pages 127-145 in Stony the Road We Trod: African American Biblical Interpretation. Edited by Cain H. Felder. Minneapolis: Fortress Press, 1991.

Conradie, Ernst M. Christian Identity: An Introduction. Stellenbosch: Sun Press, 2005.

Draper, Jonathan. "Confessional Western Text-Centered Biblical Interpretation and Oral Residual Text." Semeia 73 (1996): 59-77.

Eichrodt, Walther. Theology of the Old Testament. Volume 2. London: London University Press, 1967.

Felder, Cain H. "Race, and Biblical Narratives." Pages 165-186 in Stony the Road We Trod: African American Biblical Interpretation. Edited by Cain H. Felder. Minneapolis: Fortress Press, 1991.

Fiensy, David. "Using Nuer Culture of Africa in Understanding the Old Testament: Evaluation.” Journal for the Study of Old Testament 38 (1987): 73-83. 
50 Adamo, "The Task and Distinctiveness," OTE 28/1 (2015): 31-52

Gitau, Samson N. “A Comparative Study of Transmissions, Actualization and Stabilization of Oral Traditions: An Examination of Traditions of Circumcision in Africa and Ancient Israel." Ph.D. Dissertation, Boston University, 1994.

Hinga, Teresa. "Reading With: An Exploration of the Interface Between Critical and Ordinary Readings of the Bible: A Response." Semeia 73 (1996): 277-284.

Holter, Knut. "Should Old Testament Cush be Rendered African?" The Bible Translator 48 (1997): 331-336. . "It is Not Only a Question of Money! African Old Testament Scholarship between the Myths and Meanings of the South and the Money and Methods of the North." Old Testament Essays 11 (1998): 240-254. . Yahweh in Africa: Essays on Africa and the Old Testament. Bible and Theology in Africa 1. New York: Peter Lang, 2000. . "Africa in the Old Testament." Pages 569-581 in The Bible in Africa: Transactions, Trajectories, and Trends. Edited by Gerald O. West and Dube Musa. Leiden: Brill, 2000.

. "Does A Dialogue between Africa and Europe Make Sense?" Pages 70-83 in African and European Readers of the Bible in Dialogue. Edited by Hans de Wit and Gerald O. West. Pietermaritzburg: Cluster Publications, 2009.

Hoyland, Marta. "An African Presence in the Old Testament? David Tuesday Adamo's Interpretation of the Old Testament Cush Passages." Old Testament Essays 11 (1998): 50-58.

."The African Texts of the Old Testament and their African Interpretations." Pages 43-54 in Interpreting the Old Testament in Africa. Edited by Mary Getui, Knut Holter, and Victor Zinkuratire. New York: Peter Lang, 2001.

Jacob, Edmond. Theology of the Old Testament. London: London University Press, 1958.

Jonker, Louis. "Toward a Communal Approach for Reading the Bible in Africa." Pages 76-88 in Interpreting the Old Testament in Africa. Edited by Mary Getui, Knut Holter, and Victor Zinkuratire. New York: Peter Lang, 2001.

Kawale, Winston R. "God and Nature in Genesis 1:1-2:4 and Chewa Cosmogony." Ph.D. Dissertation, University of Stellenbosch, South Africa, 1998.

Kisirinya, Serapio Kabazzi. "Interpreting the Old Testament in Africa: Last Will, Contract or Covenant." Pages 189-192 in Interpreting the Old Testament in Africa. Edited by Mary Getui, Knut Holter and Victor Zinkuratire. New York: Peter Lang, 2001.

Kittel, Gerhard and Gerhard Friedrich, eds. Theological Dictionary of the New Testament. Grand Rapids, Mich.: WM Eerdmans Publ., 1967.

Knight, G. A. F. A Biblical Approach to the Doctrine of the Trinity. Edinburgh: T \& T Clark, 1953.

Krahmalkov, Charles R. Phoenician-Punic Dictionary. Leuven: Peeters, 2000.

Masenya, Madipoane (ngwan'a Mphahlele). "Wisdom and Wisdom Converge: Selected Old Testament and Northern Sotho Proverbs." Pages 133-146 in Interpreting the Old Testament in Africa. Edited by Mary Getui, Knut Holter, and Victor Zinkuratire. New York: Peter Lang, 2001.

. "A Small Herb Increases Itself (Makes Impact) by a Strong Odour': Reimagining Vashti in an African South African Context." Old Testament Essays 16/2 (2003): 332-342. 
Adamo, "The Task and Distinctiveness," OTE 28/1 (2015): 31-52

."For Better for Worse? The (Christian) Bible and Africana Women." Old Testament Essays 22/1 (2009): 126-150.

McFall, Ernest A. Approaching the Nuer through the Old Testament. Pasadena: William Carey Library, 1970.

Mulrain, George. "Hermeneutics within a Caribbean Context." Pages 116-132 in Vernacular Hermeneutics. Edited by R. S. Sugirtharajah. Sheffield: Sheffield Academic Press, 1999.

Nthaburi, Zablonand Douglas Waruta. "Biblical Hermeneutics in African Instituted Churches." Pages 40-57 in The Bible in African Christianity. Edited by Hannah W. Kinoti and John M. Walligo. Nairobi: Acton Publishers, 1997.

Okure, Teresa. "Africans in the Bible: A Study of Hermeneutics." Paper presented at the annual meeting of SBL, New Orleans, Nov 22-26, 1996.

Otieno, Pauline. "Interpreting the Book of Psalms in the Coptic Orthodox Church of Kenya." Pages 159-164 in Interpreting the Old Testament in Africa. Edited by Mary Getui, Knut Holter and Victor Zinkuratire. New York: Peter Lang, 2001.

Patte, Daniel. "Biblical Scholars at the Interface between Critical and Ordinary Readings: A Response.” Semeia 73 (1996): 263-276.

Riches, John. "Interpreting the Bible in African Contexts: Glasgow Consultation." Semeia 73 (1996): 181-188.

Smart, Ninian. The Religious Experience of Mankind. New York: Collins, 1969. . The Phenomenon of Religion. London: Mowbrays, 1973.

Smoak, Jeremy. "Amuletic Inscriptions and the Background of YHWH as Guardian and Protector in Psalm 12." Vetus Testamentum 60 (2010): 421-432.

."Prayers of Petition in the Psalms and West Semitic Inscribed Amulets: Efficacious Words in Metal and Prayers for Protection in Biblical Literature." Journal for the Study of Old Testament 36/1 (2011): 75-92.

Sugirtharajah, Rasiah S. "Thinking about Vernacular Hermeneutics Sitting in a Metropolitan Study.” Pages 92-115 in Vernacular Hermeneutics. Edited by Rasiah S. Sugirtharajah. Sheffield: Sheffield Academy Press, 1999. . "Vernacular resurrections: An Introduction." Pages 11-19 in Vernacular Hermeneutics. Edited by Rasiah S. Sugirtharajah. Sheffield: Sheffield Academy Press, 1999.

Swanepoel, Michael G. "An Encounter between Old Testament Theology and African Concepts of God." Theologia viatorum 18 (1990): 20-30.

Thielton, Anthony C. "The Supposed Power of Words." Journal of Theological Studies 25/2 (1974): 183-299.

Ukpong, Justin. "Reading the Bible with African Eyes: Inculturation and Hermeneutics." Journal of Theology for Southern Africa 91 (1995): 3-14. "Development in Biblical Interpretation in Africa: Historical and Hermeneutical Directions." Pages 11-28 in The Bible in Africa. Edited by Gerald West and Musa Dube. Boston: Brill, 2000. . "Bible Reading with a Community of Bible Readers." Pages 188-212 in Interpreting the New Testament in Africa. Edited by Mary Getui, Tinyiko Maluleke and Justin Ukpong. Nairobi: Acton Press, 2001. . "Inculturation Hermeneutics: An African Approach to Biblical Interpretation." Pages 17-32 in The Bible in A World Context: An Experiment in Contextual Hermeneutics. Edited by Walter Dietrich and Ulrich Luz. Grand Rapids: William B. Eerdmans Publishing Company, 2002. 
52 Adamo, "The Task and Distinctiveness," OTE 28/1 (2015): 31-52

Von Rad, Gerhard. Old Testament Theology. Volume 2. Edinburgh: T \& T Clark, 1965.

Wafawanaka, Robert. "Perspective on the Problem of Poverty in Traditional Africa and in Ancient Israel." Ph.D. Dissertation, Boston University, 1997.

."Reading the Bible Differently: Giving Shape to the Discourses of the Dominated." Semeia 73 (2001): 21-41.

."Unpacking the Package that is the Bible in African Biblical Scholarship." Pages 65-94 in Reading the Bible in the Global Village: Cape Town. Edited by Alpheus Masoga, Norman K. Gottwald, Tinyiko S. Maluleke, Justin S. Ukpong, Gerald O. West, Jeremy Punt, Vincent L. Wimbush, and Musa W. Dube.

Society of Biblical Literature: Global Perspectives on Biblical Scholarship 8. Atlanta: Society of Biblical Literature, 2002.

. "Interrogating the Comparative Paradigm in African Biblical Scholarship."

Pages 37-64 in African and European Readers of the Bible in Dialogue. Edited by Hans de Wit and Gerald O. West. Pietermaritzburg: Cluster Publications, 2009.

Wimbush, Vincent. "Scripture for Strangers: The Making of an Africanized Bible." Pages 162-177 in Postcolonial Interventions. Edited by Tat-Siong Liew. Sheffield: Sheffield Phoenix Press, 2009.

Yorke, Gosnell L. "Biblical Hermeneutics: An Afrocentric Perspective." Journal of Religion and Theology 2/2 (1995): 145-158.

Zulu, Edwin. "A Ngoni Assessment of the Role of Ancestors within Israelite Worldviews and Religion in Genesis 11:28-50:26." Ph.D. Dissertation, University of Stellenbosch, South Africa, 1999.

Prof. David Tuesday Adamo, Research Fellow, Department of Biblical and Ancient Studies, UNISA and member of the Department of Philosophy and Religious Studies, Kogi State University, Anyigba, Kogi State, Nigeria. E-mail: adamodt@yahoo.com. 